DOI: https://doi.org/10.31933/jemsi.v2i2 Received: 21 November 2020, Revised: 25 Desember 2020, Publish: 3 Januari 2021

\begin{tabular}{|c|c|c|}
\hline DINASTI & $\begin{array}{l}\text { JURNAL EKONOMI MANAJEMEN } \\
\text { SISTEM INFORMASI }\end{array}$ & $\begin{array}{r}\text { https://dinastirev.org/JEMISI } \\
\text { editor@dinastirev.org } \\
08117401455 @\end{array}$ \\
\hline
\end{tabular}

\title{
ANALISIS KEUANGAN SEBAGAI DASAR UNTUK MENGUKUR KINERJA PT ADARO ENERGY TBK PERIODE 2014-2019
}

\author{
Fourmarch Sinaga ${ }^{1)}$ \\ 1)Universitas Marcu Buana, Jakarta, Indonesia, fourmarchsinaga@yahoo.com \\ Corresponding Author: Fourmarch Sinaga ${ }^{1)}$
}

\begin{abstract}
Abstrak: Banyaknya perusahaan baru yang bermunculan mendorong perusahaan untuk tetap menjaga kualitas perusahaan dan lebih efisien dalam meningkatkan kemampuan menghasilkan laba. Perusahaan secara periodik mengeluarkan laporan keuangan sebagai pengolahan data dengan melakukan perhitungan lebih lanjut untuk mengetahui apakah perusahaan telah mencapai standar kinerja yang dipersyaratkan atau belum. Penelitian ini bertujuan untuk mengetahui kinerja keuangan pada PT Adaro Energy, Tbk ditinjau dari analisis rasio. Analisis rasio keuangan, membantu untuk mengetahui tingkat kinerja keuangan suatu perusahaan. Metode analisis yang digunakan adalah analisis deskriptif menggunakan rasio likuiditas, solvabilitas, aktivitas, profitabilitas, dan Du Pont system. Berdasarkan rasio likuiditas, solvabilitas, aktivitas secara berurutan perusahaan berada dalam keadaan yang baik, insolvable, tidak stabil. Berdasarkan rasio profitabilitas, perusahaan berada pada posisi yang baik sedangkan Du Pont System, perusahaan berada pada posisi yang kurang baik karena perusahaan tidak efektif dalam menggunakan aktiva yang dimiliki dalam menghasilkan laba.
\end{abstract}

Kata Kunci: Rasio Keuangan, Du Pont System, Kinerja Perusahaan

\section{PENDAHULUAN}

Perusahaan sebagai salah satu bentuk organisasi pada umumnya memiliki tujuan yang ingin dicapai dalam dunia bisnisnya, yaitu mencapai keuntungan maksimal. Hal ini menyebabkan persaingan di antara para pelaku usaha juga semakin kompetitif. Semakin banyaknya jumlah pesaing, maka setiap perusahaan harus mampu menjalankan kinerja perusahaan dengan baik.

Perkembangan dalam dunia usaha semakin ketat, dewasa ini banyak perusahaan baru yang bermunculan, sehingga mendorong perusahaan untuk tetap menjaga kualitas perusahaan dan lebih efisien dalam meningkatkan kemampuan menghasilkan laba. Untuk mencapai laba yang maksimal, manager di tuntut untuk memahami kinerja keuangan perusahaan dengan baik, melakukan analisis yang dapat menjadikan perusahaan lebih maju, kondisi dan situasi perusahaan yang harus selalu dipantau. Menurut Kamaludin dan Indriani (2011) Laporan keuangan adalah hasil akhir dari suatu proses pencatatan yang merupakan suatu ringkasan dari transaksi keuangan yang terjadi selama tahun buku yang bersangkutan. 
Perusahaan secara periodik selalu mengeluarkan laporan keuangan yang dibuat oleh bagian akunting dan diberikan kepada pihak-pihak yang berkepentingan, misalnya pemerintah, kreditor, pemilik perusahaan dan pihak manajemen sendiri. Selanjutnya, pihak-pihak tersebut akan melakukan pengolahan data dengan melakukan perhitungan lebih lanjut untuk mengetahui apakah perusahaan telah mencapai standar kinerja yang dipersyaratkan atau belum. Untuk mengetahui apakah laporan keuangan dalam perusahaan dalam kondisi yang baik dapat dilakukan berbagai analisa, seperti analisa rasio dan $d u$ pont system.

Analisis rasio keuangan, membantu mengetahui tingkat kinerja keuangan perusahaan apakah baik atau sebaliknya. Analisis rasio dapat diklasifikasikan dalam berbagai jenis, beberapa di antaranya yaitu rasio likuiditas, solvabilitas, aktivitas dan profitabilitas. Tingkat likuiditas adalah menunjukan sejauh mana kemampuan perusahaan dalam memenuhi kewajiban jangka pendeknya dengan jaminan harta lancar yang dimilikinya. Sedangkan tingkat solvabilitas, menunjukkan sejauh mana kemampuan perusahaan dapat memenuhi semua kewajibannya dengan jaminan harta yang dimilikinya. Tingkat aktivitas, mengukur efektivitas suatu perusahaan dalam menggunakan aktiva yang dimilikinya. Tingkat profitabilitas, menunjukkan sejauh mana kemampuan perusahaan dalam menghasilkan laba dengan modal yang dimilikinya.Apakah perusahaan - perusahaan yang kelihatan besar sudah bisa menyatakan keefektifan kinerja perusahaan tersebut. Dengan mengetahui tingkat likuiditas, solvabilitas, aktivitas dan profitabilitas suatu perusahaan, akan dapat diketahui keadaan perusahaan yang sesungguhnya sehingga dapat diukur tingkat kinerja keuangan dalam perusahaan.

Menurut Sugiono (2009:89) Du-Pont sistem memberikan suatu kerangka analisis yang menghubungkan berbagai macam rasio, yaitu menghubungkan mata rantai new profit margin (yang mengukur profitabilitas) dengan assets turn over yang mengidentifikasi efisiensi perusahaan dalam menggunakan assetnya untuk menghasilkan penjualan.

Berdasarkan latar belakang yang dipaparkan penulis, penulis akan memaparkan analisis laporan keuangan PT Adaro Energy, Tbk. Penelitian ini bertujuan untuk mengetahui kinerja keuangan pada PT Adaro Energy, Tbk ditinjau dari analisa rasio keuangan dan Du Pont System.

\section{KAJIAN PUSTAKA}

\section{Laporan Keuangan}

PSAK No. 1 tentang Penyajian Laporan Keuangan (revisi 2009) menyatakan laporan keuangan adalah suatu penyajian terstruktur dari posisi keuangan dan kinerja keuangan suatu entitas. Jadi laporan keuangan merupakan salah satu informasi yang sangat penting dalam menilai perkembangan perusahaan. Laporan keuangan dapat digunakan untuk menilai prestasi yang dicapai perusahaan pada saat lampau, sekarang dan rencana pada waktu yang akan datang.

Menurut Susilo (2009:10) menyatakan bahwa laporan keuangan adalah hasil akhir dari proses akuntansi yang memuat informasi-informasi dan memberikan keterangan-keterangan mengenai data ekonomi perusahaan yang terdiri dari daftar-daftar yang menunjukan posisi keuangan dan hasil kegiatan perusahaan untuk satu periode yang meliputi neraca, laporan laba rugi dan laporan perubahan keuangan.

Tujuan laporan keuangan yaitu untuk menyediakan informasi yang berkaitan dengan posisi keuangan, prestasi (hasil usaha) perusahaan serta perubahan posisi keuangan suatu perusahaan yang bermanfaat bagi pemakai dalam pengambilan keputusan ekonomi. PSAK No. 1tentang Penyajian Laporan Keuangan (revisi 2009) menyatakan tujuan laporan keuangan adalah memberikan informasi mengenai posisi keuangan, kinerja keuangan, dan arus kas entitas yang bermanfaat bagi sebagian besar kalangan pengguna laporan dalam pembuatan keputusan ekonomi. 


\section{Analisis Laporan Keuangan}

Menurut Munawir (2010:35), analisis laporan keuangan adalah analisis laporan keuangan yang terdiri dari penelaahan atau mempelajari daripada hubungan dan tendensi atau kecenderungan (trend) untuk menentukan posisi keuangan dan hasil operasi serta perkembangan perusahaan yang bersangkutan.

Sedangkan pengertian analisis laporan keuangan menurut Harahap (2006: 190) adalah sebagai berikut: "analisis laporan keuangan yaitu menguraikan pos-pos laporan keuangan menjadi unit informasi yang lebih kecil dan melihat hubungannya yang bersifat signifikan atau yang mempunyai makna antara satu dengan yang lainnya baik antara data kuantitatif maupun data nonkuantitatif dengan tujuan untuk mengetahui kondisi keuangan lebih dalam yang sangat penting dalam proses menghasilkan keputusan yang sangat tepat”.

\section{Rasio Keuangan}

Menganalisis laporan keuangan berarti mengevaluasi tiga karakteristik dari perusahaan, yaitu likuiditas, aktivitas, solvabilitas, profitabilitas yang menjadi faktor prnting yang harus diperhatikan oleh penganalisa.

1. Likuiditas menunjukan kemampuan suatu perusahaan untuk memenuhi kewajiban keuangannya yang harus segera dipenuhi, atau kemampuan perusahaan untuk memenuhi kewajiban pada saat ditagih.

2. Profitabilitas menunjukan kemampuan perusahaan untuk menghasilkan laba selama periode tertentu.

3. Solvabilitas menunjukan kemampuan perusahaan untuk memenuhi kewajiban keuangan apabila perusahaan tersebut dilikuidasikan baik kewajiban keuangan jangka pendek maupun jangka panjang.

4. Aktivitas menunjukan kemampuan perusahaan untuk mengukur seberapa efektif hasil guna perusahaan menggunakan sumber dayanya.

Secara umum, rasio keuangan dibagi menjadi 4 jenis, antara lain: rasio likuiditas, rasio solvabilitas, rasio aktivitas, dan rasio profitabilitas.

\section{Du Pont System}

Pada tahun 1920-an, Du Pont Corporation memelopori salah satu metoda analisa kinerja perusahaan yang sampai dengan saat ini dikenal dengan nama Analisis Du Pont. Dimana Analisis Sistem Du Pont adalah analisis yang mencakup seluruh rasio aktivitas dan margin keuntungan atas penjualan untuk menunjukkan bagaimana rasio ini mempengaruhi profitabilitas (Weston dan Bringham, 1994).

Analisis $\mathrm{Du}$ Pont menggabungkan rasio-rasio aktivitas dan profit margin, dan menunjukkan bagaimana rasio-rasio tersebut berinteraksi untuk menentukan profitabilitas aktivaaktiva yang dimiliki perusahaan. Jika rasio perputaran dikalikan dengan margin laba penjualan, hasilnya adalah tingkat pengembalian aktiva (ROA) atau sering disebut juga tingkat pengembalian investasi (ROI) Sawir (2012). ROI menunjukkan kemampuan perusahaan menghasilkan laba dari aktiva yang digunakan Sartono (2012).

\section{METODE PENELITIAN}

Jenis Penelitian 
Jenis penelitian yang dilakukan berupa studi deskriptif yang meliputi pengumpulan data untuk diuji hipotesis atau menjawab pertanyaan mengenai status terakhir dari subjek penelitian. (Kuncoro 2009:12).

\section{Metode Pengumpulan Data}

Sumber data yang digunakan dalam penelitian ini adalah data sekunder. Data sekunder dapat didefinisikan sebagai "data yang dikumpulkan oleh pihak lain" (Kuncoro, 2009:148). Data dalam penelitian ini, datasekunder berupa dokumen yang diperoleh dari IDX/Bursa Efek Indonesia malalui internet yang ada kaitannya dengan penelitian ini. Data yang digunakan pada penelitian ini diperoleh dari laporan keuangan pada perusahaan PT Adaro Energy, Tbk tahun 2014 sampai dengan 2019.

\section{Metode Analisis}

Metode analisa yang digunakan adalah metode analisa horizontal. Kasmir (2008:69) menyatakan metode analisa horizontal yaitu membandingan laporan keuangan untuk beberapa periode. Dari hasil analisis ini akan terlihat perkembanganperusahaan dari periode satu ke periode yang lain. Faktor-faktor utama yang harus diperhatikan oleh penganalisa adalah rasio likuiditas, rasio solvabilitas, rasio aktivitas, rasio profitabilitas dan Du Pont System.

\section{HASIL DAN PEMBAHASAN}

\section{Gambaran Umum Perusahaan}

Adaro Energy Tbk.(Kode saham pada BEI:ADRO.JK) adalah Perusahaan Indonesia yang merupakan produsen batu bara terbesar di belahan bumi selatan dan keempat terbesar di dunia. CEO Garibaldi Thohir (orang Indonesia) memiliki kira-kira seperenam saham dari Adaro, senilai lebih dari \$ 1 miliar.

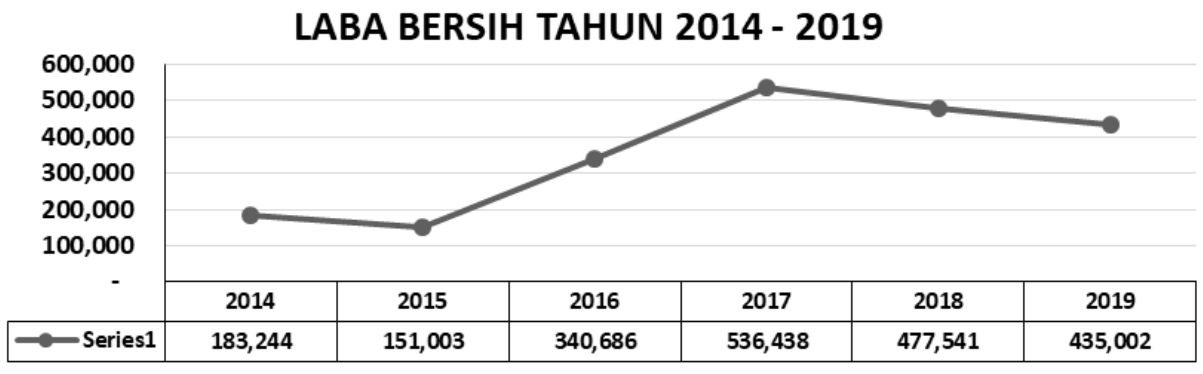

Grafik 1. Laba Bersih PT Adaro Energy, Tbk tahun 2014 sampai dengan 2019

\section{Hasil Penelitian}

1. Rasio Likuiditas, yang dihitung dengan cara:

Current Ratio

$$
=\frac{\text { Aktiva Lancar }}{\text { Utang Lancar }}
$$

Quick Ratio

$$
=\frac{\text { Aktiva Lancar }- \text { Persediaan }}{\text { Utang Lancar }}
$$


2. Rasio Solvabilitas, yang dihitung dengan cara:

$\begin{array}{ll}\text { Total Debt Ratio } & =\frac{\text { Total Aktiva }- \text { Total Ekuitas }}{\text { Total Aktiva }} \\ \text { Debt Equity Ratio } & =\frac{\text { Total Utang }}{\text { Total Ekuitas }} \\ \text { Equity Multiplier } & =\frac{\text { Total Aktiva }}{\text { Total Ekuitas }} \\ \text { Capital Structure } & =\frac{\text { Utang Jangka Panjang }}{\text { Total Ekuitas }}\end{array}$

3. Rasio Aktivitas, yang dihitung dengan cara:

$\begin{array}{ll}\begin{array}{l}\text { Receivables Turn Over } \\ \text { Days Sales in Receivables } \\ \text { (satuan: hari) }\end{array} & =\frac{\text { Penjualan }}{\text { Piutang }} \\ \begin{array}{c}\text { Inventory Turn Over } \\ \text { (satuan: hari) }\end{array} & =\frac{365}{\text { Receivables Turn Over }} \\ \text { Days Sales in Inventory } & \text { Persediaan } \\ \text { Total Asset Turn Over } & =\frac{365}{\text { Inventory Turn Over }}\end{array}$

4. Rasio Profitabilitas, yang dihitung dengan cara:

$\begin{array}{ll}\text { Profit Margin } & =\frac{\text { Laba Bersih }}{\text { Penjualan }} \\ \text { Return On Asset } & =\frac{\text { Laba Bersih }}{\text { Total Aktiva }} \\ \text { Return On Equity } & =\frac{\text { Laba Bersih }}{\text { Total Ekuitas }}\end{array}$

5. Du Pont System, yang dihitung dengan cara:

Return On Asset $=$ Profit Margin x Total Asset Turn Over x 100\%

\section{Analisis}

1. Rasio Likuiditas, yang dihitung dengan cara: 
Tabel 1. Rasio Likuiditas PT Adaro Energy, Tbk tahun 2014 sampai dengan 2019

\begin{tabular}{|l|r|r|r|r|r|r|}
\hline \multicolumn{1}{|c|}{ Jenis Rasio } & \multicolumn{1}{c|}{2014} & \multicolumn{1}{c|}{2015} & 2016 & 2017 & 2018 & 2019 \\
\hline LIKUIDITAS (satuan: kali) \\
\hline Current Ratio & 2.09 & 3.23 & 2.40 & 1.95 & 1.97 & 1.40 \\
\hline Quick Ratio & 1.96 & 3.07 & 2.28 & 1.84 & 1.83 & 1.30 \\
\hline
\end{tabular}

\section{RASIO LIKUIDITAS}

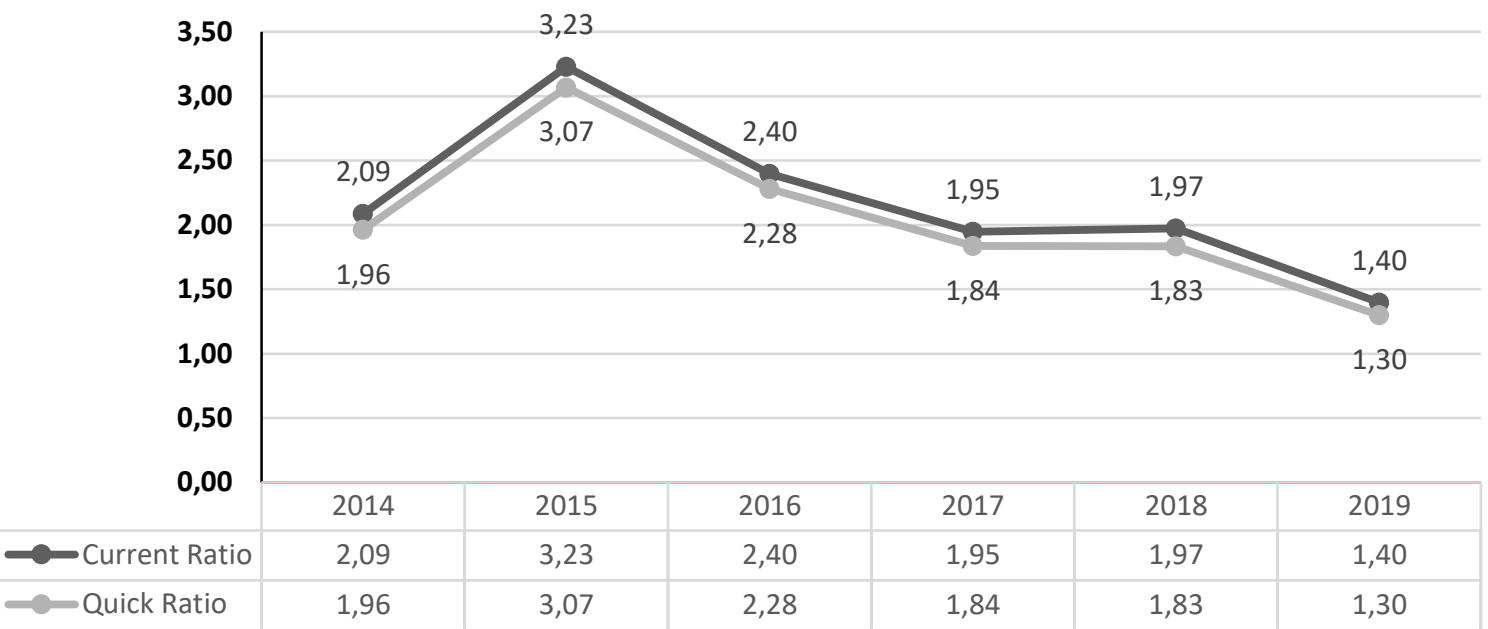

Grafik 2. Rasio Likuiditas PT Adaro Energy, Tbk tahun 2014 sampai dengan 2019

2. Rasio Solvabilitas, yang dihitung dengan cara:

Tabel 2. Rasio Solvabilitas PT Adaro Energy, Tbk tahun 2014 sampai dengan 2019

\begin{tabular}{|l|r|r|r|r|r|r|}
\hline \multicolumn{1}{|c|}{ Jenis Rasio } & \multicolumn{1}{c|}{2014} & \multicolumn{1}{c|}{2015} & \multicolumn{1}{c|}{2016} & 2017 & 2018 & 2019 \\
\hline \multicolumn{7}{|c|}{ SOLVABILITAS (satuan: kali) } \\
\hline Total Debt Ratio & 0.49 & 0.44 & 0.42 & 0.40 & 0.39 & 0.45 \\
\hline Debt Equity Ratio & 0.97 & 0.78 & 0.72 & 0.67 & 0.64 & 0.81 \\
\hline Equity Multiplier & 1.97 & 1.78 & 1.72 & 1.67 & 1.64 & 1.81 \\
\hline Capital Structure & 0.73 & 0.64 & 0.55 & 0.48 & 0.45 & 0.50 \\
\hline
\end{tabular}




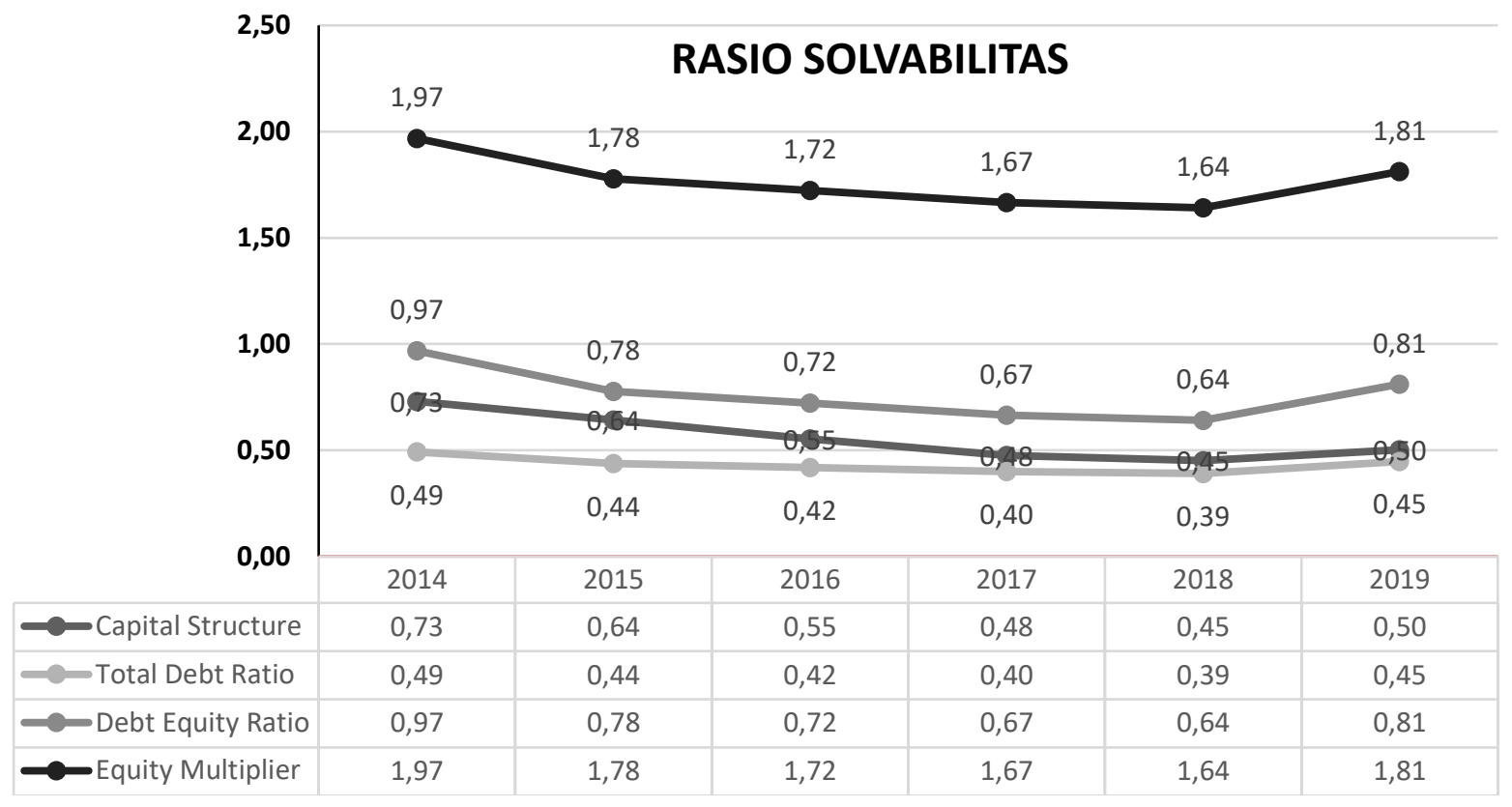

Grafik 3. Rasio Solvabilitas PT Adaro Energy, Tbk tahun 2014 sampai dengan 2019

3. Rasio Aktivitas, yang dihitung dengan cara:

Tabel 3. Rasio Aktivitas PT Adaro Energy, Tbk tahun 2014 sampai dengan 2019

\begin{tabular}{|c|c|c|c|c|c|c|}
\hline Jenis Rasio & 2014 & 2015 & 2016 & 2017 & 2018 & 2019 \\
\hline \multicolumn{7}{|c|}{ AKTIVITAS } \\
\hline Receivables Turn Over & 11.58 & 13.55 & 8.33 & 10.14 & 9.60 & 10.82 \\
\hline Days Sales in Receivables & 32 & 27 & 44 & 36 & 38 & 34 \\
\hline Inventory Turn Over & 26.93 & 29.42 & 25.05 & 24.77 & 21.51 & 20.59 \\
\hline Days Sales in Inventory & 14 & 12 & 15 & 15 & 17 & 18 \\
\hline Total Asset Turn Over & 0.52 & 0.45 & 0.39 & 0.48 & 0.51 & 0.48 \\
\hline
\end{tabular}

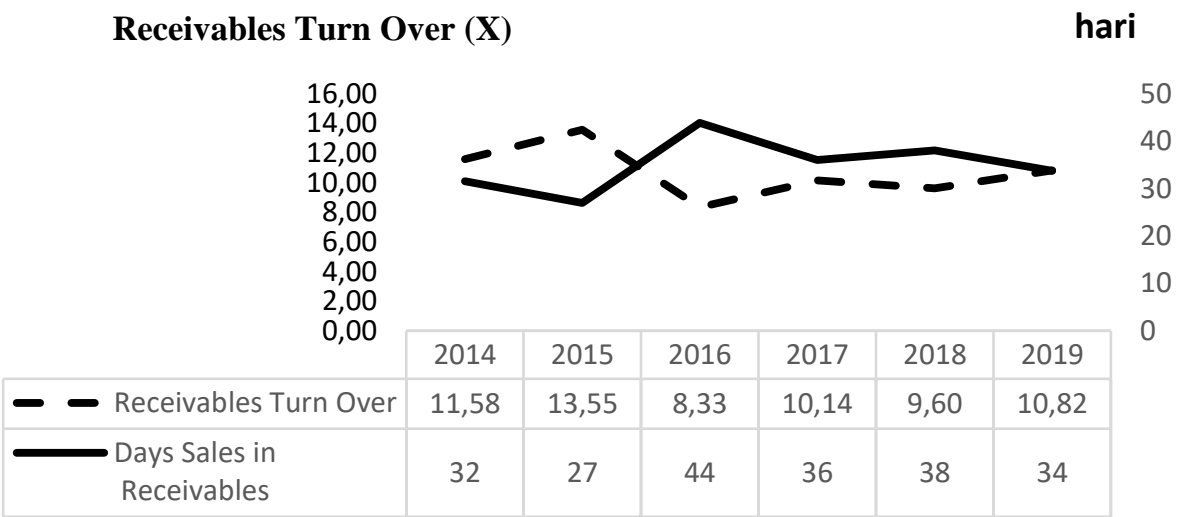

Grafik 4. Rasio Aktivitas PT Adaro Energy, Tbk tahun 2014 sampai dengan 2019 


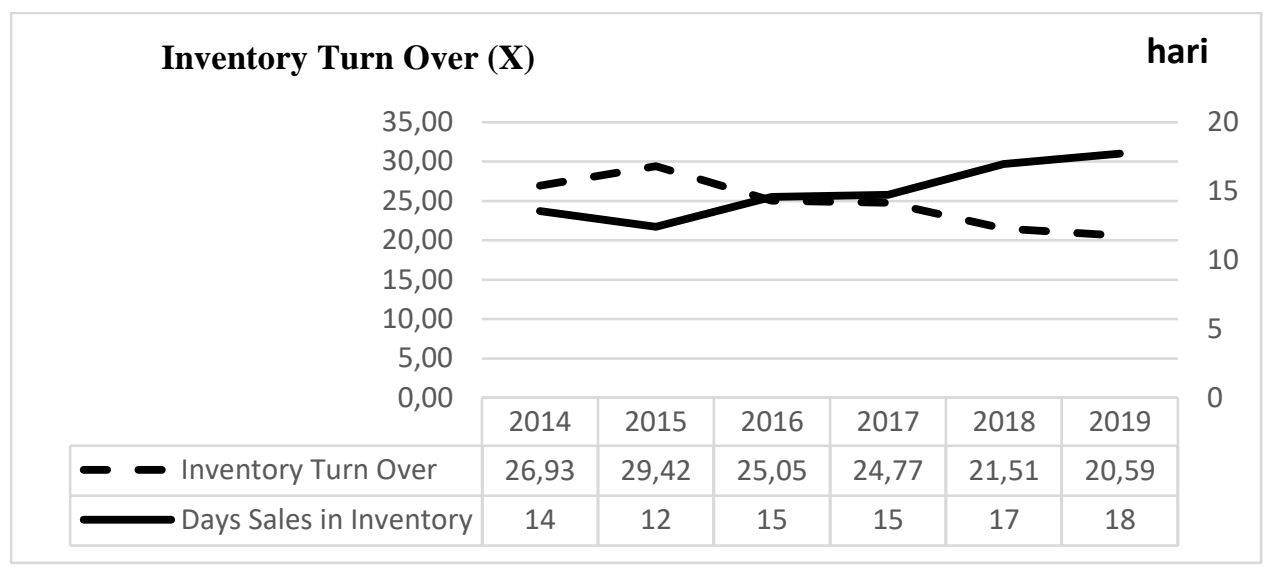

\section{Total Asset Turn Over (X)}

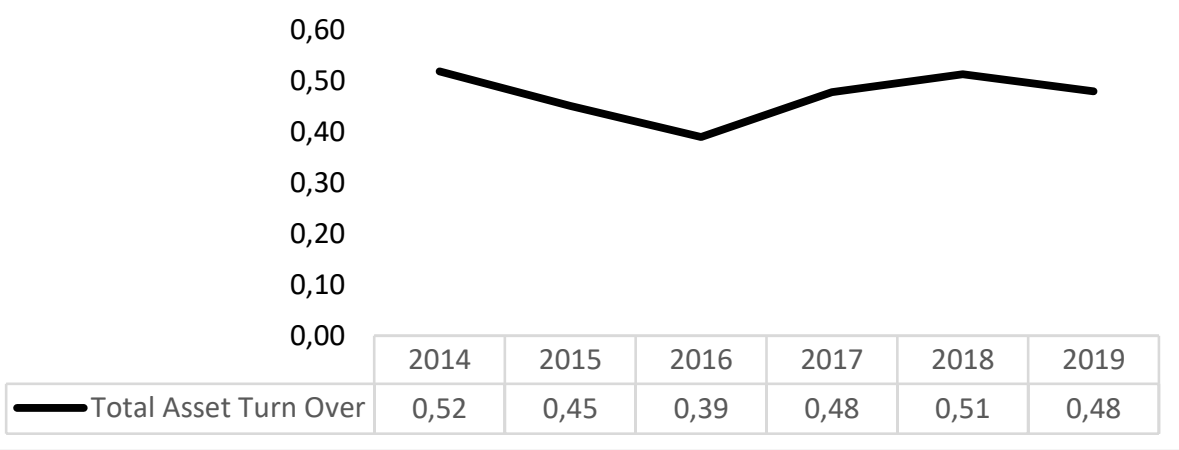

4. Rasio Profitabilitas, yang dihitung dengan cara:

Tabel 4. Rasio Profitabilitas PT Adaro Energy, Tbk tahun 2014 sampai dengan 2019

\begin{tabular}{|c|c|c|c|c|c|c|}
\hline Jenis Rasio & 2014 & 2015 & 2016 & 2017 & 2018 & 2019 \\
\hline \multicolumn{7}{|c|}{ PROFITABILITAS (satuan: \%) } \\
\hline Profit Margin & $5.51 \%$ & $5.63 \%$ & $13.40 \%$ & $16.46 \%$ & $13.19 \%$ & $12.58 \%$ \\
\hline Return On Asset & $2.86 \%$ & $2.53 \%$ & $5.22 \%$ & $7.87 \%$ & $6.76 \%$ & $6.03 \%$ \\
\hline Return On Equity & $5.62 \%$ & $4.50 \%$ & $9.00 \%$ & $13.11 \%$ & $11.10 \%$ & $10.92 \%$ \\
\hline
\end{tabular}




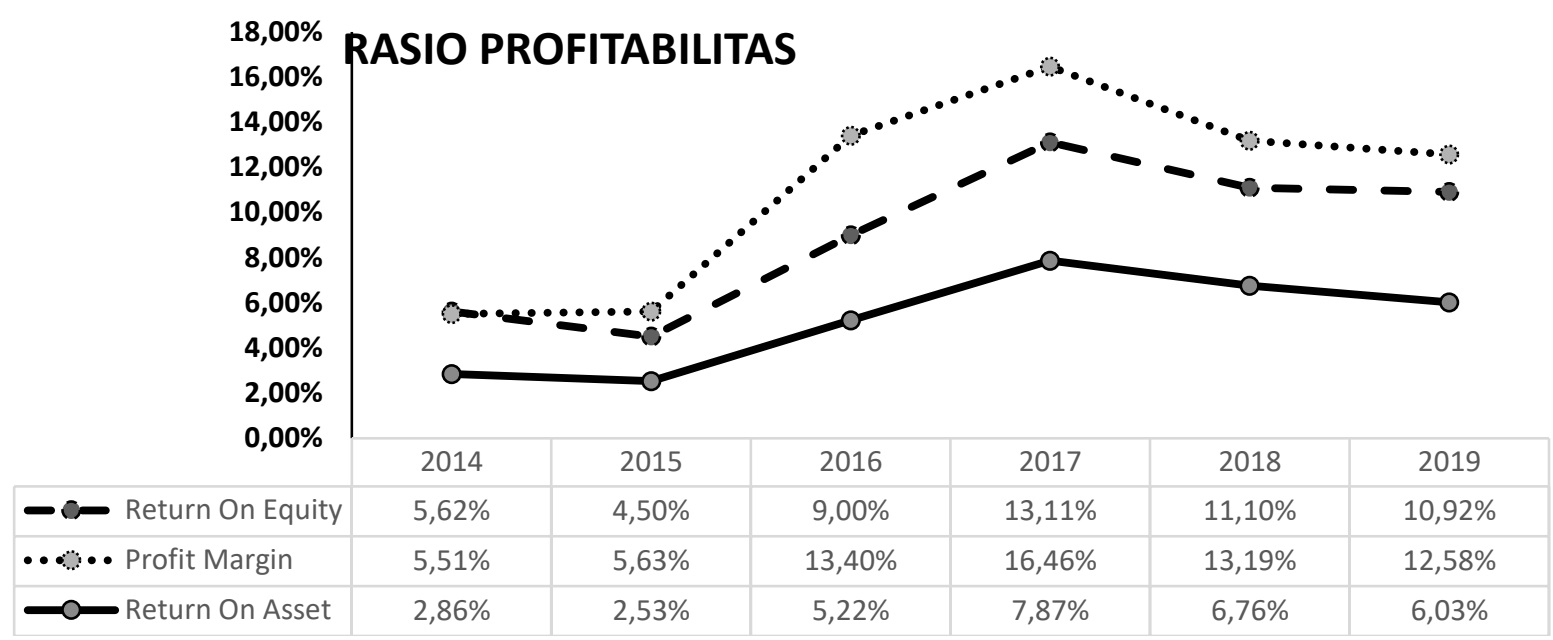

Grafik 5. Rasio Profitabilitas PT Adaro Energy, Tbk tahun 2014 sampai dengan 2019

5. Du Pont System, yang dihitung dengan cara:

Tabel 5. Du Pont System PT Adaro Energy, Tbk tahun 2014 sampai dengan 2019

\begin{tabular}{|c|c|c|r|}
\hline \multirow{2}{*}{ KETERANGAN } & $\begin{array}{l}\text { PM } \\
(\boldsymbol{\%})\end{array}$ & $\begin{array}{c}\text { TATO } \\
\text { (kali) }\end{array}$ & $\begin{array}{c}\text { ROA } \\
(\boldsymbol{\%})\end{array}$ \\
\cline { 2 - 4 } & $\mathbf{1}$ & $\mathbf{2}$ & $\mathbf{3 = 1 \times 2 \times 1 0 0 \%}$ \\
\hline 2014 & $5.51 \%$ & 0.52 & $2.86 \%$ \\
\hline 2015 & $5.63 \%$ & 0.45 & $2.53 \%$ \\
\hline 2016 & $13.40 \%$ & 0.39 & $5.22 \%$ \\
\hline 2017 & $16.46 \%$ & 0.48 & $7.87 \%$ \\
\hline 2018 & $13.19 \%$ & 0.51 & $6.76 \%$ \\
\hline 2019 & $12.58 \%$ & 0.48 & $6.03 \%$ \\
\hline Rata - Rata & $\mathbf{0 . 1 1}$ & $\mathbf{0 . 4 7}$ & $\mathbf{0 . 0 5}$ \\
\hline
\end{tabular}

Sumber: Data diolah dari laporan keuangan PT Adaro Energy Tbk 


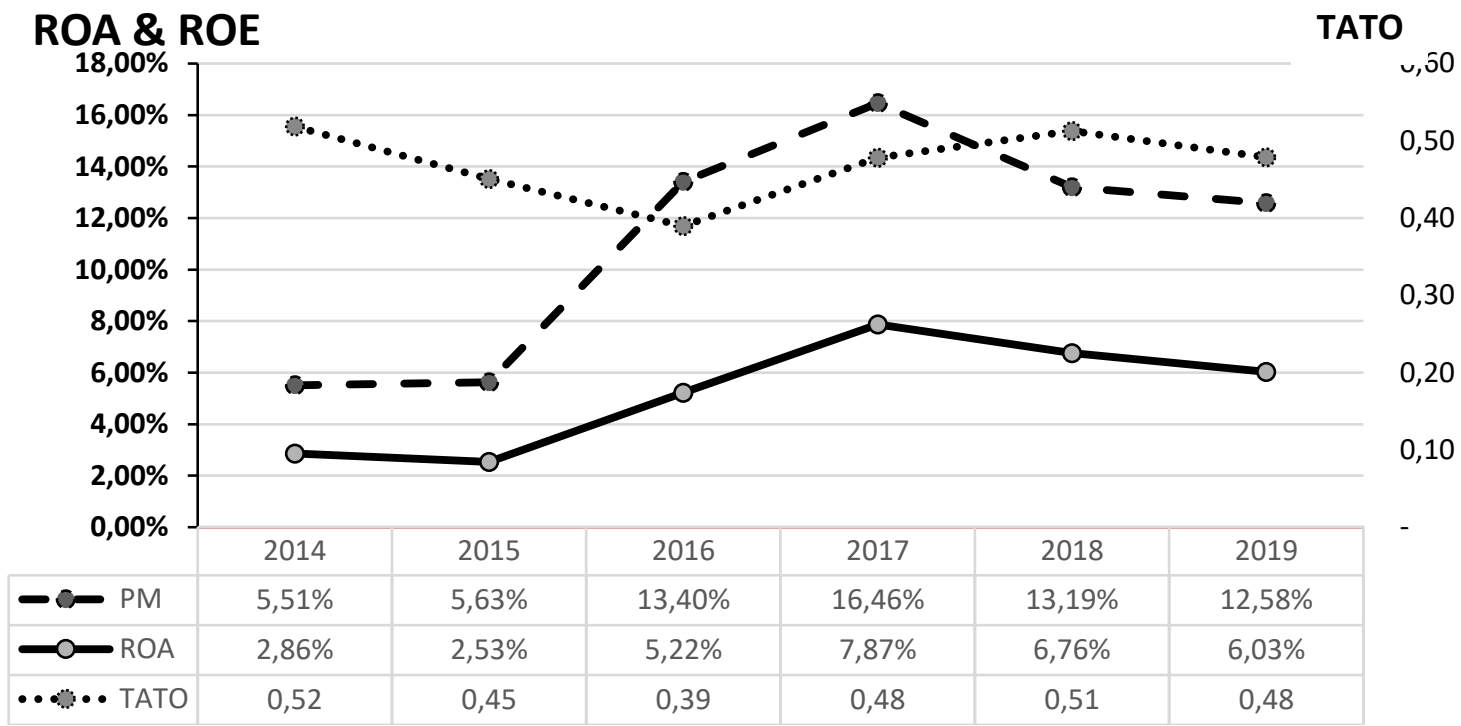

Grafik 6. Du Pont System PT Adaro Energy, Tbk tahun 2014 sampai dengan 2019

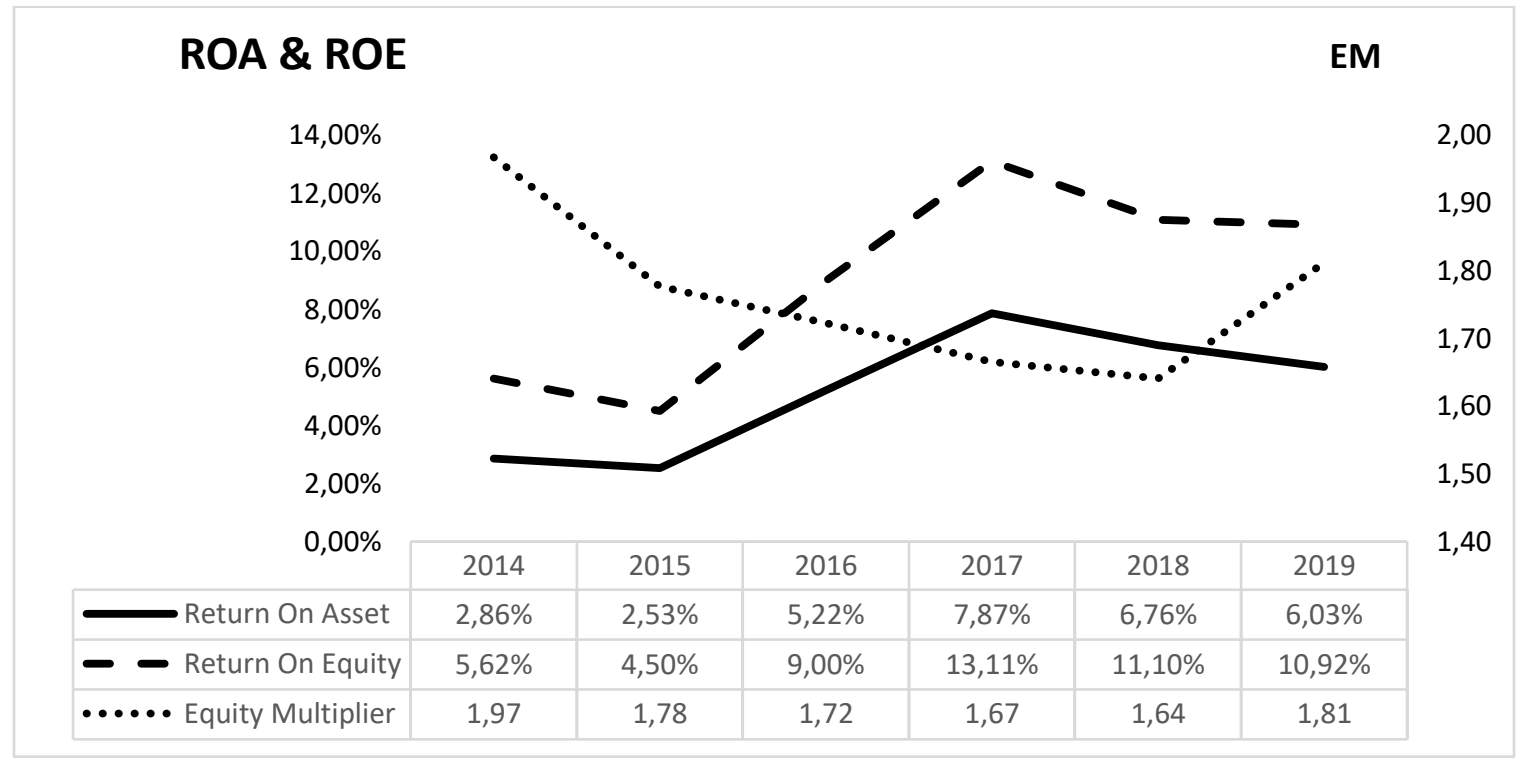

\section{PEMBAHASAN}

1. Rasio Likuiditas

Ditinjau dari rasio likuiditas memiliki rata-rata current ratio dan quick ratio berturutturut adalah 2.17x dan 2.05x. Hal ini menunjukkan secara keseluruhan keadaan perusahaan dalam kondisi yang baik. Hal ini dapat kita lihat pada nilai current ratio dan quick ratio bahwa pada dasarnya mengalami peningkatan. Semakin tinggi atau besarnya nilai rasio likuiditas ini menandakan bahwa keadaan perusahaan berada dalam kondisi baik atau liquid. Liquid yaitu keadaan dimana perusahaan dinyatakan sehat dan dalam keadaan baik karena mampu melunasi kewajiban jangka pendek. Pada tahun 2019 nilai current ratio dan quick ratio mengalami 
penurunan. Hal ini disebabkan karena terjadi peningkatan utang lancar di tahun 2019 sebesar 50.97\% dibandingkan tahun 2018, selain itu aktiva lancar tahun 2019 mengalami penurunan sebesar $6.47 \%$ dibandingkan tahun 2018 .

2. Rasio Solvabilitas

Ditinjau dari rasio solvabilitas, keadaan perusahaan sedikit mengkhawatirkan. Hal ini dapat dilihat dari total debt ratio pada tahun 2014 mencapai $0.49 x$. Hal ini berarti semua pendanaan PT Adaro Energy, Tbk yaitu mencapai 49\% berasal dari kreditor. Pada tahun 2015 mengalami penurunan $11.09 \%$ dibandingkan tahun 2014, sehingga mencapai total debt ratio sebesar 0.44x. Pada tahun 2016 mengalami penurunan 4.06\% dibandingkan tahun 2015, sehingga mencapai total debt ratio sebesar 0.42. Pada tahun 2017 mengalami penurunan $4.77 \%$ dibandingkan tahun 2018, sehingga mencapai total debt ratio sebesar 0.40x. Pada tahun 2018 mengalami penurunan $2.23 \%$ dibandingkan tahun 2019, sehingga mencapai total debt ratio sebesar 0.39x. Pada tahun 2019 mengalami kenaikan 14.71\% dibandingkan tahun 2018, sehingga mencapai total debt ratio sebesar $0.45 \mathrm{x}$.

Debt equity ratio pada tahun 2014 mencapai angka 0.97x artinya 97\% utang dibiayai oleh modal. Pada tahun 2015 mengalami penurunan 19.70\% dibandingkan tahun 2014, sehingga mencapai Debt equity ratio sebesar 0.78x. Pada tahun 2016 mengalami penurunan 6.99\% dibandingkan tahun 2015, sehingga mencapai Debt equity ratio sebesar 0.72x. Pada tahun 2017 mengalami penurunan $7.94 \%$ dibandingkan tahun 2016, sehingga mencapai Debt equity ratio sebesar 0.67x. Pada tahun 2018 mengalami penurunan 3.66\% dibandingkan tahun 2017, sehingga mencapai Debt equity ratio sebesar 0.64x. Pada tahun 2019 mengalami kenaikan 26.64\% dibandingkan tahun 2018, sehingga mencapai Debt equity ratio sebesar 0.81x.

Equity multiplier pada tahun 2014 mencapai angka 1.97x artinya 97\% aktiva dibiayai oleh modal. Pada tahun 2015 mengalami penurunan 9.69\% dibandingkan tahun 2014, sehingga mencapai Equity multiplier sebesar 1.78x. Pada tahun 2016 mengalami penurunan 3.06\% dibandingkan tahun 2015, sehingga mencapai Equity multiplier sebesar 1.72x. Pada tahun 2017 mengalami penurunan 3.33\% dibandingkan tahun 2016, sehingga mencapai Equity multiplier sebesar 1.67x. Pada tahun 2018 mengalami penurunan 1.46\% dibandingkan tahun 2017, sehingga mencapai Equity multiplier sebesar 1.64x. Pada tahun 2019 mengalami kenaikan $10.41 \%$ dibandingkan tahun 2018, sehingga mencapai Debt equity ratio sebesar $1.81 \mathrm{x}$.

Capital structure pada tahun 2014 mencapai angka 0.73x artinya 73\% utang jangka panjang dibiayai oleh modal. Pada tahun 2015 mengalami penurunan $12.13 \%$ dibandingkan tahun 2014, sehingga mencapai Capital structure sebesar 0.64x. Pada tahun 2016 mengalami penurunan $13.87 \%$ dibandingkan tahun 2015, sehingga mencapai Capital structure sebesar 0.55x. Pada tahun 2017 mengalami penurunan 13.78\% dibandingkan tahun 2016, sehingga mencapai Capital structure sebesar 0.48x. Pada tahun 2018 mengalami penurunan 5.28\% dibandingkan tahun 2017, sehingga mencapai Capital structure sebesar 0.45x. Pada tahun 2019 mengalami kenaikan 11.33\% dibandingkan tahun 2018, sehingga mencapai Capital structure sebesar 0.50x. 
3. Rasio Aktivitas

Ditinjau dari receivable turn over PT Adaro Energy, Tbk pada tahun 2014 sebesar $11.58 x$, yang artinya dalam satu periode dapat mengumpulkan piutang sebanyak 12 kali yaitu selama 32 hari sekali. Pada tahun 2015 receivable turn over sebesar 13.55x, yang artinya dalam satu periode dapat mengumpulkan piutang sebanyak 14 kali yaitu selama 27 hari sekali. Pada tahun 2016 receivable turn over sebesar 8.33x, yang artinya dalam satu periode dapat mengumpulkan piutang sebanyak 9 kali yaitu selama 44 hari sekali. Pada tahun 2017 receivable turn over sebesar $10.14 \mathrm{x}$, yang artinya dalam satu periode dapat mengumpulkan piutang sebanyak 11 kali yaitu selama 36 hari sekali. Pada tahun 2018 receivable turn over sebesar 9.60x, yang artinya dalam satu periode dapat mengumpulkan piutang sebanyak 10 kali yaitu selama 38 hari sekali. Pada tahun 2019 receivable turn over sebesar 10.82x, yang artinya dalam satu periode dapat mengumpulkan piutang sebanyak 11 kali yaitu selama 34 hari sekali.

Ditinjau dari inventory turn over PT Adaro Energy, Tbk pada tahun 2014 sebesar 26.93x, yang artinya dalam satu periode dapat mengumpulkan persediaan sebanyak 27 kali yaitu selama 14 hari sekali. Pada tahun 2015 inventory turn over sebesar 29.42x, yang artinya dalam satu periode dapat mengumpulkan persediaan sebanyak 30 kali yaitu selama 12 hari sekali. Pada tahun 2016 inventory turn over sebesar 25.05x, yang artinya dalam satu periode dapat mengumpulkan persediaan sebanyak 25 kali yaitu selama 15 hari sekali. Pada tahun 2017 inventory turn over sebesar $24.77 \mathrm{x}$, yang artinya dalam satu periode dapat mengumpulkan persediaan sebanyak 25 kali yaitu selama 15 hari sekali. Pada tahun 2018 inventory turn over sebesar $21.51 \mathrm{x}$, yang artinya dalam satu periode dapat mengumpulkan persediaan sebanyak 22 kali yaitu selama 17 hari sekali. Pada tahun 2019 inventory turn over sebesar 20.59x, yang artinya dalam satu periode dapat mengumpulkan persediaan sebanyak 21 kali yaitu selama 18 hari sekali.

Ditinjau dari total asset turn over PT Adaro Energy, Tbk pada tahun 2014 adalah 0.52x. Pada tahun 2015 mengalami penurunan sebesar 13.11\% dibandingkan tahun 2014 menjadi 0.45x. Pada tahun 2016 mengalami penurunan sebesar 13.48\% dibandingkan tahun 2015 menjadi 0.39x. Pada tahun 2017 mengalami kenaikan sebesar $22.68 \%$ dibandingkan tahun 2016 menjadi 0.48x. Pada tahun 2018 mengalami kenaikan sebesar 7.21\% dibandingkan tahun 2017 menjadi 0.51x. Pada tahun 2019 mengalami penurunan sebesar $6.56 \%$ dibandingkan tahun 2018 menjadi $0.48 x$.

4. Rasio Profitabilitas

Pada tahun 2014, PT Adaro Energy, Tbk memiliki profit margin sebesar 5.51\%. Tahun 2015 mengalami kenaikan sebesar 2.08\% dibandingkan tahun 2014 menjadi 5.63\%. Tahun 2016 mengalami kenaikan sebesar $138.25 \%$ dibandingkan tahun 2015 menjadi $13.40 \%$. Tahun 2017 mengalami kenaikan sebesar $22.85 \%$ dibandingkan tahun 2016 menjadi $16.46 \%$. Tahun 2018 mengalami penurunan sebesar 19.87\% dibandingkan tahun 2017 menjadi 13.19\%. Tahun 2019 mengalami penurunan sebesar 4.62\% dibandingkan tahun 2018 menjadi $12.58 \%$.

Pada tahun 2014 return on asset PT Adaro Energy, Tbk mencapai 2.86\%. Tahun 2015 mengalami penurunan sebesar $11.20 \%$ dibandingkan tahun 2014 menjadi $2.53 \%$. Tahun 2016 mengalami kenaikan sebesar 106.12\% dibandingkan tahun 2015 menjadi 5.22\%. Tahun 2017 
mengalami kenaikan sebesar 50.71\% dibandingkan tahun 2016 menjadi 7.87\%. Tahun 2018 mengalami penurunan sebesar 14.09\% dibandingkan tahun 2017 menjadi 6.67\%. Tahun 2019 mengalami penurunan sebesar $10.88 \%$ dibandingkan tahun 2018 menjadi $6.03 \%$.

Pada tahun 2014 return on equity PT Adaro Energy, Tbk mencapai 5.62\%. Tahun 2015 mengalami penurunan sebesar 19.89\% dibandingkan tahun 2014 menjadi $4.50 \%$. Tahun 2016 mengalami kenaikan sebesar 99.82\% dibandingkan tahun 2015 menjadi 9.00\%. Tahun 2017 mengalami kenaikan sebesar 45.69\% dibandingkan tahun 2016 menjadi 13.11\%. Tahun 2018 mengalami penurunan sebesar 15.35\% dibandingkan tahun 2017 menjadi 11.10\%. Tahun 2019 mengalami penurunan sebesar $1.61 \%$ dibandingkan tahun 2018 menjadi $10.92 \%$.

5. Du Pont System

Dilihat dari return on asset PT Adaro Energy, Tbk mampu menghasilkan tingkat efektivitas aktiva terhadap laba bersih yang cukup bagus di tahun 2017 dibandingkan tahun 2014, 2015, 2016, 2018, dan 2019. Tingkat efektivitas tahun 2017 sebesar 7.87\% lebih efektif dari tahun 2014 sebesar 2.86\%, tahun 2015 sebesar 2.53\%, tahun 2016 sebesar $5.22 \%$, tahun 2018 sebesar $6.76 \%$ dan tahun 2019 sebesar $6.03 \%$. Return on asset $7.87 \%$ di tahun 2017 ini dapat diartikan setiap Rp.1 akriva yang ada di tahun 2017 dapat menghasilkan laba bersih sebesar Rp. 0.0787.

\section{KESIMPULAN}

1. Rasio Likuiditas, PT Adaro Energy, Tbk berada dalam keadaan yang baik. Hal ini dapat kita lihat pada nilai current ratio dan quick ratio bahwa pada dasarnya mengalami peningkatan. Semakin tinggi atau besarnya nilai rasio likuiditas ini menandakan bahwa keadaan perusahaan berada dalam kondisi baik atau liquid.

2. Rasio Solvabilitas, PT Adaro Energy, Tbk berada pada posisi insolvable. Hal ini dapat dilihat pada rasio solvabilitas keadaan modal perusahaan tidak mencukupi untuk menjamin hutang yang diberikan oleh kreditur.

3. Rasio Aktivitas, PT Adaro Energy, Tbk berada pada posisi cenderung tidak stabil. Hal ini dapat di lihat dari lima rasio aktivitas yang bergerak naik dan turun setiap tahunnya.

4. Rasio Profitabilitas, PT Adaro Energy, Tbk berada pada posisi yang baik. Hal ini dapat dilihat dari 3 rasio profitabilitas yang cenderung meningkat dari tahun ke tahun, hal ini menunjukkan keberhasilan perusahaan dalam meningkatkan laba.

5. Du Pont System, PT Adaro Energy, Tbk berada pada posisi yang kurang baik, rasio du pont system yang cenderung menurun. Yang artinya perusahaan tidak efektif dalam menggunakan aktiva yang dimiliki dalam menghasilkan laba. 


\section{DAFTAR RUJUKAN}

Ikatan Akuntan Indonesia. 2009. Standar Akuntansi Keuangan: PSAK No. 1 - Penyajian Laporan Keuangan. Salemba Empat. Jakarta.Hal.3.

Kasmir. 2008. Analisis Laporan Keuangan PT. Rajagrafindo Persada. Jakarta.

Kuncoro, Mudrajat. 2009. Metode Riset Untuk Bisnis dan Ekonomi. Erlangga. Jakarta.

Sartono, Agus. (2011). Manajemen Keuangan Teori dan Aplikasi. Edisi 4, Yogyakarta: BPFE-Yogyakarta.

Sugiono Arief, dan Edy Untung, (2009). Analisis Kritis Atas Laporan Keuangan, Jakarta, PT.Raja Grafindo.

Weston. J.F., E.F.Brigham. (1994). Dasar-dasar Manajemen Keuangan I dan II Edisi 10. Jakarta: Erlangga. 